\title{
Idetifikasi Keterserapan Lulusan Jurusan Administrasi Bisnis Politeknik Negeri Samarinda
}

\author{
Andi Syarifuddin ${ }^{1 *}$, Heldina Pristanti ${ }^{2}$, dan Johan Lucas ${ }^{3}$ \\ ${ }^{123}$ Program Studi Administrasi Bisnis, Politeknik Negeri Samarinda, Samarinda 75131 \\ *Correspondent Author \\ E-mail: andisyarifuddin@polnes.ac.id
}

Diterima: 28 Pebruari $2019 \quad$ Direvisi: 25 April $2019 \quad$ Disetujui: 28 Mei 2020

\begin{abstract}
Abstrak
Identifikasi keterserapan lulusan merupakan salah satu jenis penelitian kebijakan yang mengara pada proses pencarian data dan fakta tentang fenomena keterserapan sebagian besar lulusan belum maksimal sesuai dengan bidang keilmuannya sehingga patut kita sadari munculnya beberapa fenomena yang mengara ke hal tersebut. Berdasarkan hasil tracer studi alumni jurusan Administrasi Bisnis tahun 2019 yang telah bekerja di berbagai jenis industri yang ada di Kalimantan Timur telah menunjukan angka yang cukup baik disbanding tahun sebelum dimana sebagian besar atau sekitar $74 \%$ alumni terserap di berbagai sector industry dan sisanya bekerja di instansi pemerintahan dan berwirausaha mencapai (10\%) dari jumlah yang dapat diamati dilapangan.

Yang menentukan tingkat serapan lulusan di Industri sesuai dengan bidang ilmu, sangat ditentukan oleh ketersediaan sumberdaya dan memiliki kompetensin yang sesuai dengan tingkat kebutuhan keterampilan setiap pekerjaan yang terkait dengan bidang administrasi dan perkantoran. keterserapan alumni dari 5 kabupaten kota bekerja di berbagai bidang usaha.
\end{abstract}

Kata kunci: Keterserapan lulusan, jurusan administrasi bisnis, Tracer study

\begin{abstract}
The identification of Business Administration graduates absorption is one of the types of policy research that leads to the process of finding data and facts about the phenomenon of the absorption that most of graduates that are not maximized in accordance with their scientific fields with several phenomena lead to it. Based on the results of tracer studies of alumni majoring at Business Administration department in 2019 who have worked in various types of industries in East Kalimantan have shown a pretty good compared to the several years before were about $74 \%$ of alumni absorbed in various industry sectors and the rest worked in government agencies and entrepreneurship reaches (10\%).

The determine of the level of uptake the graduates in industry in accordance with the field of science, is largely determined by the availability of resources and have competencies that are in accordance with the level of skill requirements of each job related to administration and offices.
\end{abstract}

Keywords: Graduates absorption, Business Administration Department, Tracer study

\section{PENDAHULUAN}

Peningkatan pendapatan biasanya diiringi dengan pengingkatan lapangan kerja yang bersesuaian dengan tingkat keterampilan yang dimimiliki oleh tenga kerja Tingkat keterampilan tenga kerja yang memadai merupakan menggerakkan utama perputaran roda ekonomi pada 2020 mendatang. Namun di sisi lain, terjadi kenaikan jumlah pengangguran di Indonesia sebesar 10.000 orang menjadi 7,04 juta orang pada Agustus 2017 dari Agustus 2016 sebesar 7,03 juta orang. 
Pengangguran ini sebagian disebabkan oleh ketidaksesuaian antara keterampilan yang dibutuhkan oleh pengguna jasa dengan ketersediaannya di pasar kerja. Diperlukan relevansi dan kesesuaian yang lebih baik antara pendidikan tinggi sebagai penyedia sumber daya manusia dengan dunia industri sebagai pemberi kerja.

Pendidikan dan pelatihan vokasi disinyalir menjadi satuan pendidikan yang strategis, serta bisa menjadi harapan utama bagi tersedianya pekerja profesional Indonesia yang terampil, berkualitas dan kompetitif serta memeliki daya saing.

Agar mampu memenuhi kebutuhan pasar kerja dan industri, maka politeknik Negeri Samarinda perlu melakukan pembenahan strategis sehingga dapat menciptakan tenaga kerja yang profesional, aplikatif, siap kerja, tepat waktu dan inovatif. Berbagai upaya membangun kemitraan yang berkelanjutan dengan stakeholders.

Kegiatan ini sangat penting untuk dapat membenahi kekurangan atau melakukan pengembangan secara internal untuk dapat menghasilkan lulusan yang dibutuhkan pasar kerja dan industri serta memperkuat citra dari perguruan tinggi, khususnya politeknik Negri Samarinda.

Politeknik Negeri Samarinda (Polnes) merupakan salah satu pendidikan tinggi vokasi sejak tahun 1990 telah menghasilkan banyak lulusan yang telah bekerja di bebera industry baik di dalam provinsi muapun diluar Kalimantan Timur. Polnes saat ini telah memiliki 10 jurusan dan 24 Program Studi (Prodi) dan salah jurusan dari 10 (sepuluh) jurusan tersebut adalah jurusan Administrasi Bisnis. Sejak berdirinya tahun 1988 dan lulusan pertama tahun 1990 hingga lulusan trakhir tahun 2018. Saat ini Jurusan Administrasi Bisnis memiliki 2 (dua) Prodi yakni Prodi D3 Administrasi Bisnis dan Prodi D4 Manajemen Pemasaran. Jumlah lulusan 3 (tiga) tahun terakhir mencapai kurang lebih 375 orang dan sebagian besar telah bekerja diberbagai sector lapangan usaha di Kalimantan Timur.

Dari hasil penelusuran 121 alumni Administrasi Bisnis tahun 2018 menunjukan 60\% bekerja sesuai bidangnya di berbagai jenis industry dan beberapa lainnya melanjutkan pendidikannya. Hal ini menunjukan bahwa masih rendahnya tingkat serapan lulusan Administrasi Bisnis (yang bekerja sesuai bidang) meskipun telah di terapkan system pembelajaran dengan system kredit semester dan alokasi pembelajaran praktik lebih dominan dalam proses belajar mengajar ini dapat membuktikan bahwa fenomena ini mendukung bahwa lulusan Administrasi Bisnis belum terserapnya lulusan di industry secara maksimal.

Masalah utama yang menekankan dalam penelitian ini adalah " Faktor-faktor apakah yang mempengaruhi tingkat serapan lulusan Administrasi Bisnis di industry sesuai bidang, dan Jenis Indutri apakah yang dominan tempat bekerja lulusan Administrasi Bisnis sesuai bidang serta Berapakah tingkat serapan per-tahun lulusan Administrasi Bisnis di Industri 5 (lima) tahun terakhir sesuai bidang. Tujuan penelitian adalah Untuk mengetahui dan mengidentifikasi factor-faktor yang mempengaruhi tingkat serapan lulusan Administrasi Bisnis di Industri sesuai bidang; Untuk mengetahui dan mengidentifikasi Jenis Indutri dominan tempat bekerja lulusan Administrasi Bisnis sesuai bidang; Untuk menngetahui dan mengidentifikasi tingkat serapan per-tahun lulusan Administrasi Bisnis di Industri 5 (lima) tahun terakhir sesuai Ada dua kajian hasil penelitian yang relevan, antara lain sebagai berikut:

1. Penelitian yang dilakukan oleh Nugrahaeni Sukarno (2013) yang berjudul "Implementasi Kebijakan dalam Perubahan Kurikulum (Kurikulum periode 1994, 2004, 2006 \& 2013) di SMK Negeri 2 Wates, Kulon Progo, Yogyakarta", dilihat dari kompetensi isi, pembelajaran, dan penilaian. Penelitian ini menggunakan pendekatan kualitatif dengan subjek penelitian Kepala Sekolah, Wakil Kepala Sekolah bidang Kurikulum, Guru, Komite Sekolah, dan siswa yang terlibat langsung dalam Implementasi Kebijakan Sekolah dalam perubahan kurikulum.

2. Penelitian yang dilakukan oleh M. Ari Budi. (2012). Profil lulusan melalui tracer study untuk angkatan 2009 dan 2010 pada kompetensi keahlian teknik gambar bangunan di SMK Negeri 5 Banjarmasin. 


\section{Kontribusi Alumni di Perguruan Tinggi}

Alumni sebagai insan yang sudah menerima proses pendidikan yang cukup panjang dari sebuah perguruan tinggi memberikan konsekuensi timbal balik atas keilmuan yang telah dimiliki demi pengembangan perguruan tinggi tempatnya belajar. Pengembangan ini selain di dasari konsekuensi institusi pendidikan, namun juga melihat dari konsekuensi kemanusiaan, konsekuensi keagamaan dan konsekuensi kebangsaan. maka dalam hal ini akan dibahas tentang pengertian alumni dan kontribusi alumni bagi perguruan tinggi.

KonstribusiAlumni merupakan bagian dari sebuah sistem pendidikan yang menuntut adanya output dan outcome sebagai sub sistemnya yang tentunya memiliki konsekuensi tugas dan tanggung jawab tersendiri baik secara formal maupun secara moral. Alumni berperan dalam memberikan umpan balik untuk kurikulum, pengajaran dan pembelajaran.

Perguruan tinggi yang senantiasa menjaga komunikasi dan mengelola alumninya dengan baik akan mendapatkan manfaat dari alumni baik melalui pemutakhiran kurikulum, menjadikan perguruan tinggi sebagai tempat belajar bagi alumni dan pengukuran sejauh mana kebermaknaan perguruan tinggi di masyarakat melalui alumni adalah sebagai berikut: Gagasan dalam pemutakhiran kurikulum berbasis relevansi dengan kebutuhan pasar / dunia kerja; Alumni dan pekerja survei merupakan salah satu bentuk studi empiris yang dapat memberikan informasi berharga untuk mengevaluasi hasil pendidikan dan pelatihan dari lembaga tertentu pendidikan tinggi

\section{KERANGKA PIKIT}

Kesiapan SDM tersebut berupa pemahaman system pendidikan politeknik yang atur oleh oleh Kementrian Riset Teknologi Pendidikan Tinggi Republik Indonesia. Jika masih ada kekurangan, dalam implementasinya maka akan disempurnakan kedepan.

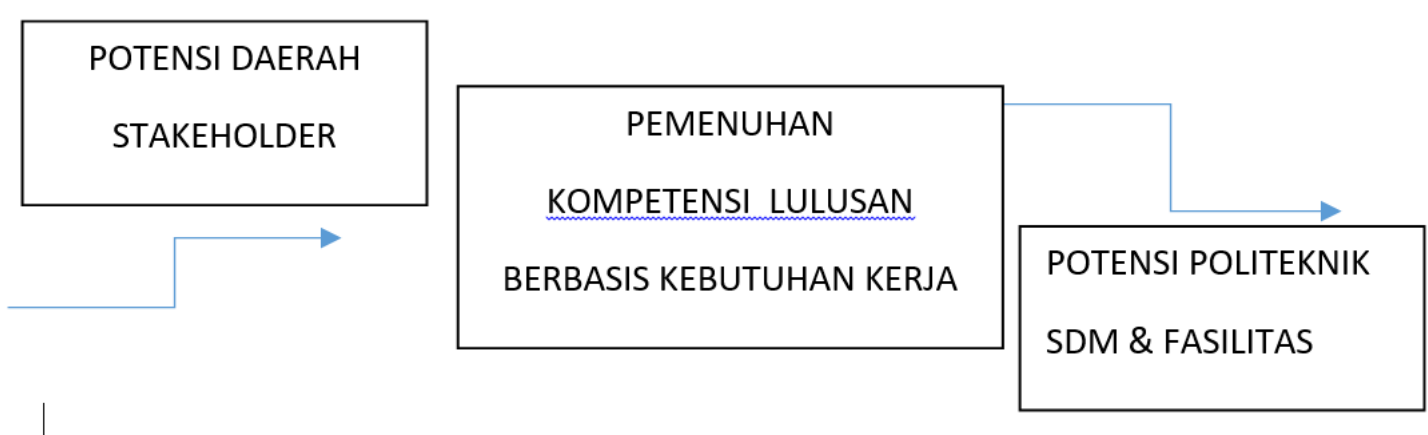

Gambar 1. Kerangka PIKIT Kesiapan SDM

\section{METODOLOGI}

Penelitian seluruh lulusan Jurusan Administrasi Bisnis Politeknik Negri Samarinda pada kohort (batasan target lulusan/alumni yang akan disurvei) 3 tahun terakhir, yaitu lulusan tahun 2016 hingga 2018, Jumlah sampel sebanyak 100 responden, dengan perincian sebagai berikut: sampel lulusan D4 Prodi Manajemen Pemasaran sejumlah 50 responden dan lulusan D3 Prodi Administrasi Bisnis sejumlah 50 orang. Methode Pengumpulan data akan dilaksanakan dengan metode kuantitatif melalui pengisian kuesioner atau angket. Penyebaran kuesioner Penyebaran kuesioner juga dilakukan melalui cara pengiriman melalui Google.com atau e-mail , Instrumen kuesioner dirancang dengan jawaban tertutup (berskala 1-5, misalnya untuk tingkat kepuasan: sangat kurang - sangat baik). Analisis Data yang diperoleh dari responden lulusan, teman sejawat, dan pengguna lulusan akan dianalisis secara deskriptif 


\section{HASIL DAN PEMBAHASAN}

Berdasarkan hasil penelitian melalui penelusuran tempat kerja alumni Jurusan Administrasi Bisnis di 5 (lima) kabupaten dan kota di Kalimantan Timur yakni kabupatem Penajam Paser Utara, Balikpapan, Samarinda, Bontang,dan Kutai Timur. Dari 5 (lima) kabupaten kota tersebut merupakan lokasi perusahaan tempat beroperasi beberapa perusahaan yang notabene sebagai pengguna alumni dengan jumlah perusahaan mencapai 37 buah. Dapat digambarkan bahwa dari 70 kuisioner yang disebarkan, ada 50 orang alumni yang mengembalikan atau mengisi kuisioner. Angkatan Lulusan yag mengisi kuisioner adalah angkatan 2012 sebesar 34\%, angkatan 2013 sebesar 28\%, angkatan 2014 sebesar 28\%, angkatan 2015 sebesar 12\%. Dari gambaran data tersebut $82 \%$ alumni telah bekerja sesuai dengan bidangnya meskipun tempat kerjanya berbedabeda, ketidak sesuai ini disebabkan karena adanya bidang pekerjaan yang sipatnya tenaga operasional dilapangan.

Dari hasil penelitian menunjukan bahwa $64 \%$ alumni mendapatkan pekerjaan kurang dari 6 ( enam ) bulan setelah wisuda, 21,6\% alumni mendapatkan pekerjaan 6 (enam) bulan setelah lulus, dan 14,4\% alumni memperoleh pekerjaan lebih dari 6 (enam) bulan setelah wisuda.

Berdasarkan status Pekerjaaan alumni yang telah diterima dan berstatus pegawai atau karyawan tetap sebesar 70,3\%, karyawan berstatus kontrak sebesar 21,6\%, dan lainnya mencapai $8,1 \%$ masih karyawan honorer. Penempatan alumni atau karyawan tetap umunya ditemukan dan didominasi pada perusahaan swasta dan lainnya pada pemerintahan. Sedangkan karyawan yang berstatus kontrak juga didominasi pada perusahaan swasta dan yang bergerak apada bidang usaha perbankan dan lembaga keuangan lainnya serta pada usaha retail.

Dengan ketersediaan sumber daya manusia yang disiapkan oleh lembaga pendidikan. Politekni Negeri Samarinda salah satu perguruan tinggi vokasi yang menyiapkan sumber daya manusia yang siap kerja khususnya pada jurusan Administrasi Bisnis. Dengan adanya tekanan pekerjaan tersebut alumni belum bisa menyesuaikan dengan kondisi tersebut sehingga diperlukan suatu pembelajaran kepada mahasiswa terkait dengan bagaimana menanamkan etos kerja yang tinggi dan memiliki soft Skill yang lebih mudah menyesuaikan dalam kondisi pekerjaan di perusahaan.

Adapun jenis industri yang ditempati bekerja alumni Program Studi Administrasi Bisnis mulai dari angkatan 2012 sampai dengan 2015 adalah sektor industri Perbankan sebanyak, Industri Perhotelan, Indusri Pertambangan dan Pengolahan, Sektor Industri Perdangan, sector manufaktur, Dealer mobil, Pegadaian, dan pada usaha jasa pengembangan permahan. Jumlah bank yang ditempati alumni bekerja sebanyak di Bank, yakni Bank Mandiri, bank Rakyat Indonesia, Bank Danamon, BTPN, Bank Kaltimtara, Bank Central Asia, dan Bank Syariah Mandiri, sedangkan lembaga keuangan lainnya berupa BCA Finance, dan Pegadaian. Untuk sector perhotelan sebanyak 3 buah yakni Hotel Aston, Hotel Haris, Victorya hotel, dan Swiss Belhotel Borneo, sektor pertambangan yakni PT Arkananta di Balikpapan, PT Kaltim Prima Coal di Sangata, dan PT Indo Minco di Bontang.

Persentase jumlah alumni yang bekerja di sector perbankan dan lembaga keuangan lainnya mencapai $20,9 \%$, di sektor industri perhotelan mencapai $19,1 \%$, di sektor, sector industry pertambangan mencapai $10,8 \%$, sector indutri usaha Perdagangan mencapai $18,1 \%$, sector Manufactur, $25 \%$, jasa pelayanan kesehatan, $0,5 \%$, dan di sector jasa pengembangan perumahan mencapai $1 \%$, dan lainnya $10,1 \%$. (mandiri)

Lokasi industri tempat alumni bekerja, 80\% di dalam kota Samarinda, dan 20\% lainnya tersebar di beberapa kota dan kabupaten. Lokasi industry sector pertambangan Sangata, Balikpapan, Samarinda, Bontang, kabupten Penajam Pasir Utara, dan Kabupaten Kutai Kartanegara. Lokasi perusahaan untuk Industri perbankan dan lembaga keuangan lainnya meliputi, Samarinda, Balikpapan dan Kabupaten Kutai Kartanegara. Sedangkan lokasi industry untuk perhotelan dan perdagangan ditemui di Samarinda kota. Jenis Indutri tersebut sebagian tergolong Badan Usaha Milik Negara, Swasta murni, dan juga usaha mandiri. 
Posisi pekerjaan alumni pada tiap perusahaan cukup bervarisi, 25,6\% ditempatkan pada tenaga operasional, $0,54 \%$ ditempatkan pada posisi tenaga pemasaran, $47 \%$ ditempatkan pada posisi administrasi, untuk posisi manager mencapai $8,1 \%$, dan untuk posisi kerjaan lainnya mencapai $18,8 \%$ yang terdiri atasa pelaku bisnis dan tenaga lapangan. Penempatan alumni pada posisi pekerjaan saat ini rata-rata sudah mencapai 5-10 tahun. Posisi pekerjaan dapat mengalami perubahan sewaktu-waktu sesuai dengan kemampuan dan penilaian dari pimpinan. Perubahan posisi pekerjaan dalam perusahaan disebabkan oleh adanya penilaian kinerja karyawan yang dilakukan setiap tahun oleh pimpinan. Penilaian yang paling utama adalah kedisiplinan kerja dan tingkat efisiensi dalam proses menylesaikan pekerjaan.

Perkembangan tingkat serapan alumni Program Studi Administrasi B

isnis Jurusan Administrasi Politeknik Negeri Samarinda untuk 4 angkatan yang telah mengisi kusioner dapat dilihat sebagai berikut:

Tabel 1. Tingkat serapan alumi Program Studi Administrasi Bisnis

\begin{tabular}{|c|c|c|c|c|c|c|c|c|}
\hline \multirow{2}{*}{ No } & \multirow{2}{*}{ Angkatan } & \multicolumn{2}{|c|}{$\begin{array}{c}\text { Jenis } \\
\text { Kelamin }\end{array}$} & \multicolumn{7}{|c|}{ Biadang Pekerjaan } \\
\cline { 3 - 9 } & & L & P & PNS & Honore & Swasta & Wiraswasta & Sutdi \\
\hline 1 & 2012 & 10 & 7 & 2 & 2 & 9 & 4 & \\
\hline 2 & 2013 & 6 & 7 & 2 & & 10 & 1 & \\
\hline 3 & 2014 & 10 & 4 & & & 14 & & \\
\hline 4 & 2015 & 2 & 4 & 2 & & 4 & & \\
\hline & Jumlah & 28 & 22 & 6 & 2 & 37 & $(10 \%)$ & \\
\hline
\end{tabular}

Dapat digambarkan bahwa dari 4 angkatan lulusan Program Studi Administrasi Bisn yang telah dilaksanakan dapat diamati sebanyak 50 (lima puluh) orang lulusan Program Studi Administrasi Bisnis yang tersebar pada berbagai perusahaan dan instansi yang memiliki jenis pekerjaan yang berbeda-beda. Dari Tabel 4.1 dapat digambarkan bahwa sebagian besar alumni bekerja diperusahaan swasta ( $74 \%)$ seperti halnya di sektor perbankan (20,9\%), di perhotelan ( $19,1 \%)$, Pertambangan $(10,8 \%)$, usaha perdagangan $(18,1)$, industry Manufaktur $(25 \%)$, Jasa kesehatan $(0,5 \%)$, jasa pengembangan perumahan $(1 \%)$, dan disektor informal atau wirausaha $(10 \%)$.

Berdasarkan persentase bidang pekerjaan lulusan program studi Administrasi Bisnis sebagian besar memiliki jiwa kewirausahaan, dan bahkan ada satu alumni yang menempati posisi direktur (direktur klistrikan Kaltim). Dari hasil FGD alumni yang dilaksanakan di kota Bontang dan kota Samarinda ternyata sebagian alumni tidak langsung mendapatkan pekerjaan.

Dari 50 orang responden (alumni) sebagian besar menyampaikan bahwa dengan kompetensi yang dimiliki setelah lulus dari Politeknik Negeri Samarinda khususnya pada jurusan Administrasi Bisnis dapat menyesuaikan dengan kebutuhan industry khususnya terkait dengan bidang administrasi bisnis, namaun beberapa user juga perpendapat bahwa lulusan prodi Administrasi bisnis yang bekerja di perusahaan perlu ditekankan pada aspek Soft skill dan kepribadian sehingga bisa bekerja dibawah tekanan, secara hard skill sudah lumayan. Berdasarkan sanggahan tersebut bahwa pendidikan hard skil yang diterima pada saat kuliah sudah dapat memberikan persiapan untuk memasuki dunia kerja.

Sementara itu sebagian besar alumni yang diamati berpandangan bahwa cukup mudah untuk mendapatkan pekerjaan setelah lulus dari Jurusan Administrasi Bisnis. Hal ini terbukti dari pekerjaan yang di geluti pada perusahaan di berbagai bidang usaha baik di pertambangan, perbankan, perhotelan dan jasa keuangan lainnya mampu dalam menyelesaikan administrasi 
dengan baik. Hal ini menujukan bahwa apa yang telah mereka dapatkan selama kuliah di Jurusan Administrasi Bisnis sudah cukup memberikal skill dan bekal dalam rangka memasuki dunia kerja dan mampu bersaing dengan karyawan lainnya yang berasal dari instansi pendidikan lainnya. Bukti menunjukan bahwa model atau strategi pembelajaran dengan proporsi praktek $60 \%$ dan teori $40 \%$ sudah mampu memberikan bekal yang cukup kepada alumni sebelum memasuki dunia kerja. Dalam kegiatan kemahasiswaa para alumni juga bersedia untuk memberikan kontribusi baik berupa material maupun bantuan pemikiran dan pandangan terkait dengan pengalaman industri kepada seluruh mahasiswa

\section{KESIMPULAN}

Dari hasil hasil analisis dalam penelitian memberi kesimpulan bahwa, Faktor Penentu keterserapan alumni yang disampaikan di beberapa perusahaan yang juga sebagai user menyatakan bahwa ketersediaan bidang pekerjaan yang terkait dengan bidang administrasi bisnis memang sangat dibutuhkan, namun kompetensi yang harus dimiliki alumni bersesuaian dengan beberapa jenis pekerjaan yang memerlukan penanganan pekerjaan secara cepat dan akurat dan tentunya memiliki tanggungjawab yang tinggi terhadap pekerjaannya.

Jenis perusahaan yang ditempat alumni cukup bervariasi mulai dari industri Perbankan dan lembaga keuangan non bank, Industri Perhotelan, Industri Pertambangan dan Pengolahan, Industri Perdangangan, industri manufaktur, dan pada usaha jasa pengembangan permahan. Adapun nama perusahaan tempat alumni bekerja saat ini adalah Bank Mandiri, bank Rakyat Indonesia, Bank Danamon, BTPN, Bank Kaltimtara, Bank Central Asia, dan Bank Syariah Mandiri, sedangkan lembaga keuangan lainnya berupa BCA Finance, dan Pegadaian. Untuk perhotel adalah Hotel Aston, Hotel Haris, Victorya hotel, dan Swiss Belhotel Borneo, sektor pertambangan yakni PT Arkananta di Balikpapan, PT Kaltim Prima Coal di Sangata, dan PT Indo Minco di Bontang, PT Sumber Alam Persada Bontang, kantor post Samarinda, kantor post Bontang, PT Unit Traktor Samarinda, PT Roberco Samarinda, Dealer Toyota dan Honda Samarinda.

Terkait dengan tingkat keterserapan lulusan program studi Administrsi Bisnis cukup tinggi terutama pada sektor sewasta mencapai $74 \%$, dan lainnya tersebar di beberapa sektor termasuk di pemerintahan yang menjadi pegawai negeri dan sebagian lainnya melakukan wirausaha dalam bidang perdagangan. Sektor sewasta tergabung dalam perusahaan Badan Usaha Milik Negara dan Sewasta murni yang umumnya bergerakan dalam bidang usaha perbankan dan perhotelan, dan sector pertambangan dan pengolahan .

\section{DAFTAR PUSTAKA}

L. Suharti and F. P. Laksono. (2012). Studi Penelusuran (Tracer Study) Terhadap Alumni Program Studi Manajemen Fakultas Ekonomika dan Bisnis Universitas Kristen Satya Wacana," in PROCEEDING call for Paper Pekan Ilmiah Dosen FEB-UKSW.

P. Bouaduo and N. Ady. (2009). Tracer Study As A Paradigm For The Enhancement Of Quality Course Programmes Devalopment in Higher Education Institutions in South Africa.

S. Indriasari. (2012). Sistem Informasi Berbasis Web untuk Membantu Kegiatan Tracer Studi Program Diploma Institut Pertanian Bogor," Jurnal Sains Terapan, vol. 2, no. II, p. 85.

R. Chandra, R. and S. Ruhama. (2014). Pengembangan E-Tracer Study pada Perguruan Tinggi," in Konferensi Nasional Sistem Informasi 2014, Makasar.

Y. Kurniawan. (2013). Sistem Informasi Gerografis Pemetaan Alumni pada Perguran Tinggi (Studi Kasus Universitas Ma Chung)," in Seminar Nasional Ilmu Komputer (SNAIK 2013), Samarinda. 
N. A. A. Bakar, A. Mustapha and K. M. Nasir. (2013). Clustering Analysis for Empowering Skills in Graduate Employability Model., Aurtralian Journal of Basic and Applied Science, vol. 7, no. 14, pp. 21-28, 2013

C. L. Simbolon, N. Kusumastuti and B. Irawan. (2013). Clustering Lulusan Mahasiswa Matematika FMIPA Untan Pontianak Menggunakan Algoritma Fuzzy C-Means, BIMASTER, vol. 2, no. 1, pp. 21-26.

D. S. Purnamasari. (2008). Web Service Sebagai Solusi Integrasi Data Pada Sistem Informasi Akademik Universitas Bina Darma, Universitas Bina Darma, Palembang. 